\title{
Heat and Helio-Thermal Units Accumulation of Peanut as Affected by Planting Dates, Potassium and Calcium Spraying
}

\section{${ }^{1}$ Intsar H.H. Al-Hilfy, ${ }^{2}$ S.A.A. Al-Salmani and ${ }^{3}$ S.A. Wahid}

${ }^{1}$ Dept. of Field Crops - Coll. of Agric. - Univ. of Baghdad. Iraq

${ }^{2}$ Dept. of Field Crops - Coll. of Agric. - Anbar Univ. Iraq

${ }^{3}$ Mesopotamia Company for Seeds Production, Ministry of Agriculture, Baghdad, Iraq

Correspondence Author: Intsar H.H. Al-Hilfy, Dept. of Field Crops - Coll. of Agric. - Univ. of Baghdad

Received date: 11 March 2018, Accepted date: 25 May 2018, Online date: 28 May 2018

Copyright: (C) 2018 Intsar H.H. Al-Hilfy, et al. This is an open-access article distributed under the terms of the Creative Commons Attribution License, which permits unrestricted use, distribution, and reproduction in any medium, provided the original author and source are cre dited.

\begin{abstract}
Two field experiment were carried out at AL-Mohamadi city, Al-Anbar in the right bank of Euphrates River during 2012 and 2013 summer seasons to study the effect of planting dates, calcium and potassium spraying on heat and helio-thermal units accumulation of peanut (Local cultivar). Factorial experiment at RCBD design with three replications and two factors for both experiments were used. First experiment had 6 planting dates ( $1^{\text {st }}$ April, $15^{\text {th }}$ April, $1^{\text {st }}$ May, $15^{\text {th }}$ May, $1^{\text {st }}$ June and $15^{\text {th }}$ June) and four levels of potassium $\left(0,4000,5000\right.$ and $\left.6000 \mathrm{mg} \mathrm{K} \mathrm{L}^{-1}\right)$. Second experiment had the same planting dates with 4 levels of calcium $(0,200,400$ and $\left.600 \mathrm{mg} \mathrm{Ca} \mathrm{L}^{-1}\right)$. Results of the first experiment showed that the plants in the second planting date (15 ${ }^{\text {th }}$ April) reached maturity and harvesting stages at 2657.8 and $2907.4^{\circ} \mathrm{C}$ and 33832 and 37192 helio-thermal units for both seasons, respectively. Increasing potassium levels caused decreasing in heat units and helio-thermal units accumulation. While results of the second experiment showed that the plants in the second planting date $\left(15^{\text {th }}\right.$ April) reached maturity and harvesting stages at 2679.5 and $2931.8^{0} \mathrm{C}$ and 34107 and 37375 helio-thermal units for both seasons, respectively. Increasing calcium levels caused increasing in heat units and helio-thermal units accumulation.
\end{abstract}

Key words: Peanut, potassium, calcium, planting dates, pod yield.

\section{INTRODUCTION}

Peanut (Arachis hypogaea L.) is an important oil crop, grown for oil and protein. Seeds contain approximately $42-52 \%$ oil,25-35\% protein and 20\% carbohydrate. Seeds also contain minerals (K, Ca, Mg, Fe and $\mathrm{Zn}$ ) and vitamins (B, E and K), with good quality and high levels of unsaturated fatty acids (50\% oleic and $30 \%$ linoleic), so it is recommended in the nutrition to reduce low-density lipoprotein (LDL) [1].

Agricultural processes, including planting dates, are factors influencing growth and production of peanut due to variations in temperatures and photoperiod from time to time, affecting most of the vital processes and seed development [2, 3, 4]. Potassium is a necessary nutrient for improving crop yield and quality owing to its role in the formation of bacterial nodes, the activation of more than 80 enzymes and its positive role in the transmission of assimilates [5, 6, 7]. Calcium is also a determining factor in the production of peanut through its effect on flowers fertilization, pods maturity and seed quality improvement $[8,9,10]$.

The climatic conditions are the main factors influencing the growth, flowering and production of peanut as the plant undergoes different growth stages. The length of each stage depends on the amount of heat and helio-thermal units accumulation [11, 12]. Heat and helio-thermal units accumulation is used to describe the timing of physiological processes and is used in plant production to estimate or predict the length of each growth stage and to determine the appropriate harvesting time for the best outcome when selecting appropriate planting date [13].

Canavar and Kaynak[14] conducted a study on the effect of planting dates in four cultivars of peanut in Southern Turkey. The amount of heat and heliothermal units accumulation were calculated to estimate their effect on the morphological and yield traits. The results indicated that the emergence, number of days to flowering, gynophore formation and maturity were affected by the amount of accumulated growing degree days (GDD) and photoperiod. Peanut cultivars required about 6-11 days, $91-146{ }^{\circ} \mathrm{C}$ GDD and 65-102 $\mathrm{h}$ of sunshine radiation for the period from planting till emergence. Likewise, peanut cultivars needed $16-32$ days, $240-455{ }^{\circ} \mathrm{C}$ GDD and $177-361 \mathrm{~h}$ of sunshine radiation from emergence till the beginning of flowering. Peanut cultivars required $10-21$ days, $231-306{ }^{\circ} \mathrm{C}$ GDD and 108-264 h of sunshine radiation to proceed from the beginning of flowering to the gynophore initiation. Finally, peanut cultivars needed about $72-114$ days, 1043-1688 ${ }^{\circ} \mathrm{C}$ GDD and 694-1122 h of sunshine radiation to proceed from gynophore initiation till maturity. There was an increased GDD, but decreased sunshine radiation from emergence till the beginning of flowering at late planting dates. Highest GDD and sunshine radiation were recorded with cultivars planted early in May. The results of studies revealed that the delay in planting date reduces the period of crop growth and pod formation, where the plants are subject to long sunshine radiation and warm temperatures. Moreover, planting in June accelerated the emergence, flowering and maturity in crop plants.

So, and due to the lack of researches in Iraq about this important economic crop, and as a result of the global warming that caused large climatic fluctuations, the current study was carried out to reveal the effect of different sowing dates and levels of potassium and calcium spraying on the accumulated temperatures and helio-thermal units in peanut.

\section{MATERIALS\& METHODS}

Two field experiments were carried out during the summer seasons of 2012 and 2013 at one of Al-Mohmadi district agricultural fields, Heet district, AlAnbar governorate, on the right bank of the Euphrates River, which is within longitude $42.82^{\circ}$ and latitude $33.63^{\circ}$ in sandy soil with climatic conditions illustrated in appendix 1, to study the effect of sowing dates and potassium and calcium spraying on the Growing degree days (GDD) and helio-thermal units (HTU) in peanut crop (local cultivar). The soil of the two experiments and crop service operations were prepared according to the recommendations [15]. First experiment: effect of sowing dates and potassium spraying on accumulated temperatures and helio-thermal units in peanut: 
A factorial experiment at randomized complete blocks design RCBD was used with three replicates. The first factor included six sowing dates $\left(1^{\text {st }}\right.$ April, $15^{\text {th }}$ April, $1^{\text {st }}$ may, $15^{\text {th }}$ May, $1^{\text {st }}$ June and $\left.15^{\text {th }} \mathrm{June}\right)$, while the second factor included three levels of potassium spraying $\left(4000,5000\right.$ and $\left.6000 \mathrm{mg} \mathrm{K} \mathrm{L}^{-1}\right)$ in addition to control treatment (sprayed with distilled water only) (K0). Potassium sulfate $\mathrm{K}_{2} \mathrm{SO}_{4}(41.5 \% \mathrm{~K})$ was used as a source of potassium. The experimental plots were 72 plots. Spraying was carried out early in the morning by a back sprayer and Al-Zahi material was used as an adhesive material at the beginning of the flowering stage as a complement to soil fertilization.

Second experiment: effect of sowing dates and calcium spraying on accumulated temperatures and helio-thermal units in peanut:

A factorial experiment at randomized complete blocks design RCBD was performed with three replicates. The first factor included the same six sowing dates used in the first experiment, while the second factor included three levels of calcium $\left(200,400\right.$ and $\left.600 \mathrm{mg} \mathrm{Ca} \mathrm{L}^{-1}\right)$ as well as the control treatment (sprayed with distilled water only) $(\mathrm{Ca} 0)$. $\mathrm{CaCl}_{2}$ was used as a calcium source $(27.2 \% \mathrm{Ca})$. The experimental plots used in this experiment were 72 plots. Spraying was performed early in the morning at the beginning of the flowering stage using aback sprayer and Al-Zahi material was used as a diffuser to break upthe surface tension.

For both experiments, climatic data regarding temperatures were collected from Abu-Ghuraib Meteorological station, Ministry of Agriculture. The recorded data were analyzed statistically by using statistical software package Genstat version (12). The least significant differences (L.S.D) at the level of 0.05 probability was employed to compare the differences among the treatment means [16]. Two measurements were calculated from emergence till maturity according to the formulae [17]:

1- Growing degree days $(G D D)$ :

$\mathrm{T}_{\max }+\mathrm{T}_{\min }$ Growing Degree Days) GDD) =

2

Where:

$\mathrm{T}_{\max }=$ maximum temperature

$\mathrm{T}_{\min }=$ minimum temperature

$\mathrm{T}_{\text {base }}=$ base temperature $\left(10^{\circ} \mathrm{C}\right)$

2- Helio-thermal units $(H T U)$ :

Helio-thermal units $($ HTU $)=$ GDD $\times$ Duration of sunshine hours

\section{RESULTS AND DISCUSSION}

Growing degree days $(G D D)$ from emergence till harvesting:

It is clear from Table 1 that the effect of sowing dates and potassium spraying levels in this trait was significant, while the interaction was non-significant for both seasons.

Plants sown in the first sowing date $\left(1^{\text {st }}\right.$ April) during 2012 and the second sowing date ( $15^{\text {th }}$ April) during 2013 reached maturity and harvesting stages when accumulated 2657.8 and $2907.4^{\circ} \mathrm{C}$ for both seasons, respectively. These accumulated GDD were more than those accumulated when plants sown on $15^{\text {th }}$ June (2078.1 and $2414.3{ }^{\circ} \mathrm{C}$ ) for both seasons, respectively. The environmental conditions differed during both seasons, where plants sown during 2013 season needed more heat units than plants sown during 2012 season, and this might be attributed to the effect of temperatures and light on growth stages at different sowing dates $[18,19]$.

Regarding potassium spraying, plants sprayed with distilled water (K0) reached maturity and harvesting stages when consumed 2459.8 and $2683.7^{\circ} \mathrm{C}$ with non-significant differences from plants sprayed with $4000 \mathrm{mg} \mathrm{K} \mathrm{L}^{-1}$, which were more than other levels (K5000 and K6000).Plants sprayed with K5000 and K6000 levels of potassium needed less accumulated GDD to reach maturity and harvesting stage owing to the differences in growth period with the using of these two levels of potassium, in addition to the positive effect of potassium in accelerating the metabolism in plants and consequently less period to reach maturity and harvesting stage [6].

Table 1: Effect of sowing dates and potassium spraying during 2012 (first row) and 2013 (second row) seasons on growing degree days $\left({ }^{\circ} \mathrm{C}\right.$ ) on peanut.

\begin{tabular}{|c|c|c|c|c|c|}
\hline \multirow[t]{2}{*}{ Sowing dates } & \multicolumn{4}{|c|}{ Potassium spraying levels $\left(\mathrm{mg} \mathrm{K} \mathrm{L}^{-1}\right)$} & \multirow[t]{2}{*}{ Means } \\
\hline & K0 & K4000 & K5000 & K6000 & \\
\hline \multirow[t]{2}{*}{$1^{\text {st }}$ April } & 2674.2 & 2658.4 & 2651.9 & 2646.8 & 2657.8 \\
\hline & 2891.1 & 2860.0 & 2843.9 & 2849.6 & 2861.2 \\
\hline \multirow[t]{2}{*}{$15^{\text {th }}$ April } & 2661.6 & 2644.8 & 2631.8 & 2620.1 & 2639.6 \\
\hline & 2916.2 & 2907.7 & 2906.3 & 2899.3 & 2907.4 \\
\hline \multirow[t]{2}{*}{$1^{\text {st }}$ may } & 2529.4 & 2415.5 & 2506.5 & 2484.7 & 2509.0 \\
\hline & 2829.7 & 2808.9 & 2898.8 & 2893.5 & 2807.7 \\
\hline \multirow[t]{2}{*}{$15^{\text {th }}$ may } & 2479.8 & 2452.8 & 2445.6 & 2451.5 & 2457.4 \\
\hline & 2479.3 & 2490.0 & 2462.9 & 2471.1 & 2475.8 \\
\hline \multirow[t]{2}{*}{$1^{\text {st June }}$} & 2326.6 & 2312.0 & 2300.9 & 2290.8 & 2307.6 \\
\hline & 2554.2 & 2560.4 & 2539.7 & 2531.3 & 2546.4 \\
\hline \multirow[t]{2}{*}{$15^{\text {th }}$ June } & 2087.0 & 2079.0 & 2083.6 & 2062.7 & 2078.1 \\
\hline & 2431.2 & 2404.8 & 2413.5 & 2407.6 & 2414.3 \\
\hline \multirow[t]{2}{*}{ Means } & 2459.8 & 2443.8 & 2436.7 & 2426.1 & \\
\hline & 2683.7 & 2672.0 & 2660.9 & 2658.7 & \\
\hline \multirow[t]{3}{*}{ L.S.D. 5\% } & Sowing dates & Potassium & \multicolumn{2}{|c|}{ Sowing dates $\times$ Potassium } & \\
\hline & 29.11 & 24.31 & \multicolumn{2}{|c|}{ N.S } & \\
\hline & 24.13 & 19.83 & \multicolumn{2}{|l|}{ N.S } & \\
\hline
\end{tabular}

The effect of sowing dates, calcium spraying levels and their interaction was significant on accumulated GDD for both seasons (Table 2).

Peanut plants sown in the first sowing date $\left(1^{\text {st }}\right.$ April) during 2012 and the second sowing date $\left(15^{\text {th }}\right.$ April) during 2013 reached maturity and harvesting stages with accumulated GDD $\left(2679.5\right.$ and $\left.2931.8^{\circ} \mathrm{C}\right)$, respectively, whereas plant sown in the sixth sowing date $\left(15^{\text {th }}\right.$ June) needed less accumulated GDD $\left(2109.0\right.$ and $2433.1^{\circ} \mathrm{C}$ ) for both seasons, respectively. It is obvious from these results that late sowing caused a reduction in the accumulated GDD during both seasons.

Plants sprayed with $600 \mathrm{mg} \mathrm{Ca} \mathrm{L}^{-1}$ reached maturity and harvesting stages with accumulated GDD $\left(2469.5\right.$ and $\left.2699.5^{\circ} \mathrm{C}\right)$ for both seasons, respectively, and didn't differ significantly from plants sprayed with $400 \mathrm{mg} \mathrm{Ca} \mathrm{L}^{-1}$ only during first season $\left(2466.2^{\circ} \mathrm{C}\right)$, but differed significantly from all other levels in the second season. Control plants $(\mathrm{Ca})$ reached maturity and harvesting stages with less accumulated GDD $\left(2459.8\right.$ and $\left.2683.7{ }^{\circ} \mathrm{C}\right)$, and this might be attributed to the role of calcium in the growth and maturity of crop plants [20].

Plants sprayed with $600 \mathrm{mg} \mathrm{Ca} \mathrm{L}^{-1}$ and sown in the third sowing date $\left(1^{\text {st }}\right.$ May) during 2012 recorded highest accumulated GDD $\left(2748.4^{\circ} \mathrm{C}\right)$, while control plants $(\mathrm{Ca} 0)$ that sown in the sixth sowing date $\left(15^{\text {th }} \mathrm{June}\right)$ consumed less accumulated GDD $\left(2087.0^{\circ} \mathrm{C}\right)$ during the same season. Plants sprayed with $600 \mathrm{mg} \mathrm{Ca} \mathrm{L}^{-}$ ${ }^{1}$ and sown in the second sowing date $\left(15^{\text {th }}\right.$ April $)$ consumed highest accumulated GDD $\left(2940.9^{\circ} \mathrm{C}\right)$ in comparison with plants sown in the sixth sowing date $\left(15^{\text {th }}\right.$ 
Citation: Intsar H.H. Al-Hilfy, et al., 2018. Heat and Helio-Thermal Units Accumulation of Peanut as Affected by Planting Dates, Potassium and Calcium Spraying. Advances in Environmental Biology., 12(5): 1-5.

June) and sprayed with $200 \mathrm{mg} \mathrm{Ca} \mathrm{L}^{-1}$ where consumed less accumulated $\operatorname{GDD}\left(2419.6^{\circ} \mathrm{C}\right)$. These variations might be due to the differences in plants response to calcium spraying at different temperatures that prevailed during different sowing dates.

Table 2: Effect of sowing dates and calcium spraying during 2012 (first row) and 2013 (second row) seasons on growing degree days $\left({ }^{\circ} \mathrm{C}\right.$ ) on peanut.

\begin{tabular}{|c|c|c|c|c|c|}
\hline \multirow[t]{2}{*}{ Sowing dates } & \multicolumn{4}{|c|}{ Calcium spraying levels $\left(\mathrm{mg} \mathrm{CaL}^{-1}\right)$} & \multirow[t]{2}{*}{ Means } \\
\hline & $\mathrm{Ca} 0$ & $\mathrm{Ca} 200$ & $\mathrm{Ca} 400$ & Ca600 & \\
\hline \multirow[t]{2}{*}{$1^{\text {st }}$ April } & 2674.2 & 2674.2 & 2689.6 & 2679.8 & 2679.5 \\
\hline & 2891.3 & 2886.6 & 2898.8 & 2901.0 & 2894.4 \\
\hline \multirow[t]{2}{*}{$15^{\text {th }}$ April } & 2661.6 & 2665.7 & 2670.6 & 2683.4 & 2670.3 \\
\hline & 2916.2 & 2938.4 & 2931.6 & 2940.9 & 2931.8 \\
\hline \multirow[t]{2}{*}{$1^{\mathrm{st}}$ may } & 2529.4 & 2537.7 & 2520.5 & 2748.4 & 2584.0 \\
\hline & 2829.7 & 2806.7 & 2815.0 & 2846.1 & 2824.4 \\
\hline \multirow[t]{2}{*}{$15^{\text {th }}$ may } & 2479.8 & 2458.4 & 2488.1 & 2516.4 & 2485.7 \\
\hline & 2479.3 & 2498.6 & 2504.1 & 2482.0 & 2491.0 \\
\hline \multirow[t]{2}{*}{$1^{\text {st }}$ June } & 2326.6 & 2301.0 & 2312.5 & 2328.6 & 2317.2 \\
\hline & 2554.2 & 2569.9 & 2571.0 & 2583.7 & 2569.7 \\
\hline \multirow[t]{2}{*}{$15^{\text {th }}$ June } & 2087.0 & 2103.1 & 2115.7 & 2130.2 & 2109.0 \\
\hline & 2431.2 & 2419.6 & 2437.9 & 2443.5 & 2433.1 \\
\hline \multirow[t]{2}{*}{ Means } & 2459.8 & 2461.3 & 2466.2 & 2469.5 & \\
\hline & 2683.7 & 2686.6 & 2690.4 & 2699.5 & \\
\hline \multirow[t]{3}{*}{ L.S.D. 5\% } & Sowing dates & Calcium & \multicolumn{2}{|c|}{ Sowing dates $\times$ Calcium } & \\
\hline & 9.2 & 6.9 & \multicolumn{2}{|c|}{18.1} & \\
\hline & 10.8 & 8.8 & \multicolumn{2}{|l|}{21.7} & \\
\hline
\end{tabular}

Table 3: Effect of sowing dates and potassium spraying during 2012 (first row) and 2013 (second row) seasons on accumulated helio-thermal units (HTU) in peanut.

\begin{tabular}{|c|c|c|c|c|c|}
\hline \multirow{2}{*}{ Sowing dates } & \multicolumn{4}{|c|}{ Potassium spraying levels $\left(\mathrm{mg} \mathrm{K} \mathrm{L}^{-1}\right)$} & \multirow{2}{*}{ Means } \\
\hline & K0 & K4000 & K5000 & K6000 & \\
\hline \multirow[t]{2}{*}{$1^{\text {st }}$ April } & 34088 & 33877 & 33693 & 33668 & 33832 \\
\hline & 37947 & 37029 & 37012 & 37032 & 37030 \\
\hline \multirow[t]{2}{*}{$15^{\text {th }}$ April } & 33794 & 33770 & 33747 & 33762 & 33768 \\
\hline & 37201 & 37199 & 37194 & 37172 & 37192 \\
\hline \multirow[t]{2}{*}{$1^{\text {st }}$ may } & 32742 & 32731 & 32720 & 32696 & 32722 \\
\hline & 36330 & 36316 & 36307 & 36298 & 36313 \\
\hline \multirow[t]{2}{*}{$15^{\text {th }}$ may } & 30848 & 30821 & 30814 & 30823 & 30827 \\
\hline & 35355 & 35388 & 35338 & 35347 & 35357 \\
\hline \multirow[t]{2}{*}{$1^{\text {st }}$ June } & 28525 & 28498 & 28483 & 28459 & 28491 \\
\hline & 34029 & 34042 & 34017 & 34009 & 34024 \\
\hline \multirow[t]{2}{*}{$15^{\text {th }}$ June } & 26301 & 26193 & 26197 & 26175 & 26192 \\
\hline & 31283 & 31258 & 31271 & 31262 & 31269 \\
\hline \multirow[t]{2}{*}{ Means } & 31033 & 30982 & 30942 & 30930 & \\
\hline & 35208 & 35205 & 35189 & 35187 & \\
\hline \multirow[t]{3}{*}{ L.S.D. 5\% } & Sowing dates & Potassium & \multicolumn{2}{|c|}{ Sowing dates $\times$ Potassium } & \\
\hline & 177.8 & 143.9 & \multicolumn{2}{|c|}{ N.S } & \\
\hline & 153.6 & N.S & \multicolumn{2}{|l|}{ N.S } & \\
\hline
\end{tabular}

Accumulated helio-thermal (HTU) units from emergence till harvesting:

It is noted from Table 3 that the sowing dates significantly affected this trait for both seasons and potassium spraying levels in the first season only, while the interaction between both factors was non-significant during both seasons. The maximum accumulated HTU were recorded at first sowing date ( $1^{\text {st }}$ April) during 2012 season and the second sowing date ( $15^{\text {th }}$ April) during 2013 season (33832 and 37192), respectively. Plants sown late at sixth sowing date (15 June) needed less HTU to reach maturity and harvesting stages (26192 and 31269) for both seasons, respectively. This might be due to the differences in photoperiod during growth stages at different sowing dates [3].

Control treatment plants (K0) needed highest accumulated HTU to reach maturity and harvesting stages (31033), while the lowest accumulated HTU were recorded with plants sprayed with 5000 and $6000 \mathrm{mg} \mathrm{K} \mathrm{L}^{-1}(30942$ and 30930), respectively during 2012 season.

It is clear from Table 4 that the sowing date shad a significant effect on this trait for both seasons, where as the effect of calcium spraying and the interaction between the two factors were significant during 2012 season only.

Highest accumulated HTU were recorded on $1^{\text {st }}$ April during 2012 season, and on $15^{\text {th }}$ April during 2013 season (34107 and 37375), respectively, whereas plants sown late in the sixth sowing date $\left(15^{\text {th }}\right.$ June) needed less HTU to reach maturity and harvesting stages (24402 and 31285) for both seasons, respectively. This decrease in this trait at late sowing dates might be due to increased temperatures that led to rapid growth and early maturity in plants which caused a reduction in the days from sowing till maturity and consequently less HTU (Appendix 1). These results are in agreement with those obtained by Patel et al. [21] who declared that the environmental conditions significantly affected the growth of peanut plants.

Plants sprayed with $200 \mathrm{mg} \mathrm{Ca} \mathrm{L}^{-1}$ recorded highest HTU (31059), whereas lowest HTU were observed in plants sprayed with $400 \mathrm{mg} \mathrm{Ca} \mathrm{L}^{-1}$ (30463) during 2012 season.

Table 4: Effect of sowing dates and calcium spraying during 2012 (first row) and 2013 (second row) seasons on accumulated helio-thermal units (HTU) in peanut.

\begin{tabular}{|c|c|c|c|c|c|}
\hline \multirow[t]{2}{*}{ Sowing dates } & \multicolumn{4}{|c|}{ Calcium spraying levels $\left(\mathrm{mg} \mathrm{CaL}^{-1}\right)$} & \multirow[t]{2}{*}{ Means } \\
\hline & $\mathrm{Ca} 0$ & $\mathrm{Ca} 200$ & $\mathrm{Ca} 400$ & Ca600 & \\
\hline \multirow[t]{2}{*}{$1^{\text {st }}$ April } & 34088 & 34130 & 34111 & 34100 & 34107 \\
\hline & 35947 & 35938 & 35958 & 35964 & 35952 \\
\hline \multirow[t]{2}{*}{$15^{\text {th }}$ April } & 33910 & 33911 & 33942 & 33973 & 33934 \\
\hline & 37201 & 37435 & 37419 & 37446 & 37375 \\
\hline \multirow[t]{2}{*}{$1^{\text {st }}$ may } & 32742 & 32756 & 32729 & 32768 & 32749 \\
\hline & 36330 & 36288 & 36314 & 36361 & 36323 \\
\hline \multirow[t]{2}{*}{$15^{\text {th }}$ may } & 30848 & 30829 & 30861 & 30886 & 30881 \\
\hline & 35355 & 35372 & 35388 & 35363 & 35370 \\
\hline
\end{tabular}


Citation: Intsar H.H. Al-Hilfy, et al., 2018. Heat and Helio-Thermal Units Accumulation of Peanut as Affected by Planting Dates, Potassium and Calcium Spraying. Advances in Environmental Biology., 12(5): 1-5.

\begin{tabular}{|l|l|l|l|l|}
\hline $1^{\text {st }}$ June & 28525 & 28496 & 28507 & 28534 \\
\cline { 2 - 4 } & 34029 & 34045 & 34050 & 34067 \\
\hline \multirow{2}{*}{$15^{\text {th }}$ June } & 26201 & 26229 & 22630 & 22549 \\
\cline { 2 - 5 } & 31283 & 31266 & 31291 & 31300 \\
\hline \multirow{2}{*}{ Means } & 31052 & 31059 & 30463 & 30485 \\
\cline { 2 - 5 } & 35208 & 35241 & 35253 & 35266 \\
\hline \multirow{3}{*}{ L.S.D. 5\% } & Sowing dates & Calcium & Sowing dates $\times$ Calcium \\
\cline { 2 - 5 } & 180.4 & 146.1 & 373.2 & N.S \\
\cline { 2 - 5 } & 183.2 & N.S & \\
\hline
\end{tabular}

Regarding the interaction, plants sprayed with $200 \mathrm{mg} \mathrm{Ca} \mathrm{L}{ }^{-1}$ and sown on $1^{\text {st }}$ April recorded highest HTU (34130), whereas lowest HTU was recorded with plants sprayed with $600 \mathrm{mg} \mathrm{Ca} \mathrm{L}^{-1}$ and sown on $15^{\text {th }}$ June (22549) during 2012 season.

Appendix 1: Maximum, minimum and mean temperatures $\left({ }^{\circ} \mathrm{C}\right)$ and day length $(\mathrm{h})$ for both 2012 and 2013 seasons.

\begin{tabular}{|c|c|c|c|c|c|c|c|}
\hline \multirow{3}{*}{$\begin{array}{l}\text { Month } \\
\text { April }\end{array}$} & \multicolumn{6}{|c|}{ Temperature $\left({ }^{\circ} \mathrm{C}\right)$} & \multirow[t]{3}{*}{ Day length (h) } \\
\hline & \multicolumn{3}{|c|}{2012} & \multicolumn{3}{|l|}{2013} & \\
\hline & Minimum & Maximum & Mean & Minimum & Maximum & Mean & \\
\hline $15-19$ & 16.48 & 29.32 & 22.90 & 15.85 & 29.94 & 22.89 & 12.96 \\
\hline $20-24$ & 13.80 & 32.36 & 23.08 & 11.60 & 27.59 & 19.59 & 13.13 \\
\hline $25-30$ & 16.85 & 35.85 & 26.35 & 13.09 & 34.72 & 23.91 & 13.23 \\
\hline \multicolumn{8}{|l|}{ May } \\
\hline $1-5$ & 21.42 & 36.72 & 29.07 & 17.91 & 26.40 & 22.15 & 13.32 \\
\hline $6-10$ & 19.48 & 38.36 & 28.92 & 20.31 & 34.79 & 27.55 & 13.41 \\
\hline $11-15$ & 19.66 & 36.78 & 28.22 & 18.23 & 33.03 & 25.91 & 13.50 \\
\hline $16-20$ & 22.38 & 38.76 & 30.57 & 20.27 & 38.02 & 29.15 & 13.74 \\
\hline $21-25$ & 20.72 & 33.78 & 27.25 & 20.60 & 37.62 & 29.11 & 14.04 \\
\hline $26-31$ & 21.27 & 37.85 & 29.56 & 27.50 & 40.26 & 33.88 & 14.10 \\
\hline \multicolumn{8}{|l|}{ June } \\
\hline $1-5$ & 22.48 & 41.04 & 31.76 & 27.50 & 40.26 & 33.88 & 14.14 \\
\hline $6-10$ & 22.30 & 40.96 & 31.63 & 27.36 & 42.72 & 35.04 & 14.18 \\
\hline $11-15$ & 24.56 & 44.66 & 34.61 & 27.76 & 43.88 & 35.82 & 14.21 \\
\hline $16-20$ & 26.68 & 43.28 & 34.98 & 27.96 & 46.02 & 36.99 & 14.22 \\
\hline $21-25$ & 23.80 & 40.96 & 32.38 & 27.80 & 44.28 & 36.04 & 14.23 \\
\hline $26-30$ & 26.44 & 41.60 & 34.02 & 28.02 & 44.08 & 36.05 & 14.22 \\
\hline \multicolumn{8}{|l|}{ July } \\
\hline $1-5$ & 23.88 & 40.92 & 32.40 & 26.98 & 45.14 & 36.06 & 14.19 \\
\hline $6-10$ & 25.44 & 42.20 & 33.82 & 27.32 & 45.46 & 36.39 & 14.16 \\
\hline $11-15$ & 25.78 & 45.70 & 36.51 & 28.44 & 47.31 & 37.87 & 14.11 \\
\hline $16-20$ & 27.72 & 47.24 & 37.48 & 30.17 & 47.63 & 38.90 & 14.07 \\
\hline $21-25$ & 28.34 & 47.66 & 38.00 & 30.50 & 48.16 & 39.33 & 13.94 \\
\hline $26-31$ & 28.61 & 46.25 & 37.43 & 30.68 & 47.91 & 39.30 & 13.53 \\
\hline \multicolumn{8}{|l|}{$\begin{array}{l}\text { August } \\
\text { Augut }\end{array}$} \\
\hline $1-5$ & 26.96 & 43.42 & 35.19 & 29.84 & 46.74 & 38.29 & 13.45 \\
\hline $6-10$ & 25.38 & 44.04 & 34.71 & 28.86 & 46.66 & 37.76 & 13.36 \\
\hline $11-15$ & 23.62 & 42.04 & 32.85 & 28.00 & 45.66 & 36.83 & 13.27 \\
\hline $16-20$ & 23.68 & 43.46 & 33.57 & 29.26 & 44.14 & 36.70 & 13.19 \\
\hline $21-25$ & 24.04 & 41.86 & 32.95 & 27.86 & 43.09 & 35.47 & 13.08 \\
\hline $26-31$ & 23.55 & 42.70 & 33.12 & 26.13 & 43.21 & 34.68 & 12.71 \\
\hline \multicolumn{8}{|l|}{ September } \\
\hline $1-5$ & 22.68 & 40.82 & 31.75 & 26.13 & 43.21 & 34.68 & 12.47 \\
\hline $6-10$ & 20.64 & 40.88 & 30.76 & 26.26 & 42.71 & 34.48 & 12.37 \\
\hline $11-15$ & 21.58 & 39.52 & 30.55 & 24.91 & 42.60 & 33.75 & 12.27 \\
\hline $16-20$ & 20.02 & 39.62 & 29.82 & 23.17 & 42.17 & 32.67 & 12.18 \\
\hline $21-25$ & 19.36 & 38.26 & 28.81 & 21.69 & 41.80 & 31.74 & 12.08 \\
\hline $26-30$ & 19.00 & 39.20 & 29.10 & 21.57 & 40.73 & 31.15 & 11.74 \\
\hline \multicolumn{8}{|l|}{ October } \\
\hline $1-5$ & 19.06 & 38.96 & 29.01 & 20.30 & 41.11 & 30.70 & 11.48 \\
\hline $6-10$ & 21.18 & 35.68 & 28.43 & 21.21 & 40.41 & 30.81 & 11.38 \\
\hline $11-15$ & 16.74 & 34.30 & 25.52 & 19.27 & 38.31 & 28.79 & 11.27 \\
\hline $16-20$ & 18.36 & 32.68 & 25.52 & 19.01 & 37.17 & 28.09 & 11.18 \\
\hline $21-25$ & 16.82 & 28.42 & 22.62 & 17.15 & 35.21 & 26.18 & 11.08 \\
\hline $26-31$ & 13.30 & 27.72 & 20.53 & 15.92 & 33.11 & 24.51 & 10.71 \\
\hline \multicolumn{8}{|l|}{ November } \\
\hline $1-5$ & 15.00 & 30.90 & 22.95 & 15.77 & 31.41 & 23.59 & 10.47 \\
\hline
\end{tabular}

\section{REFERENCES}

[1] Isleib, T.G., M.B.L. Tillman, H.E. Pattee, T.H. Sanders, K.W. Hendrix and L.O. Dean, 2008. Genotype-by-environment interaction for flavor attributes of breeding lines in the uniform peanut performance test. Peanut Sci., 35: 55-60.

[2] Al-Hilfy, I.H.H., 2001. Effect of dates for planting and harvesting on yield and quality of peanut (Arachis hypogaea L.). Ph.D. Dissertation, Dept. of Field Crops, Coll. of Agric., Univ. of Baghdad, pp: 110.

[3] Calishkan, S.M., E. Calishkan, M. Arsl and H. Ariogu, 2008. Effects of sowing date and growth duration on growth and yield of groundnut in a Mediterranean- type environment in Turkey. Field Crops Res., 105(1-2): 131-14.

[4] Meena, R.S., R.S. Yadav and V.S. Meena, 2014. Response of groundnut (Arachis hypogaeaL.) verities to sowing dates and NP fertilizers under Western dry zone of India. Bangladesh J. Bot., 43(2): 169-137. 
[5] Helmy, A.M. and M.F. Ramdan, 2014. Yield quality parameters and chemical composition of peanut as affected by potassium and gypsum application under foliar spraying with boron. Communications in Soil Science and Plant Analysis, 45(18): 2397-2412.

[6] Gashti, A.H., M.N.S. Vishekaei and M.H. Hosseinzadeh, 2012. Effect of potassium and calcium application on yield components and qualitative characteristics of peanut (Arachis hypogaea L.) in Guilan province, Iran. World Appl. Sci. J., 16(4): 540-546.

[7] Wiatrak, P.J., D.L. Wright and D. Wilson, 2006. Effect of potassium and phosphorus on the growth and yield of peanut (Arachis hypogeaL.). Peanut Sci., 3: 55-61.

[8] Al-Dulami, H.M.M., 2000. Agricultural applications on the peanut (Arachis hypogaea L.). Ph.D. Dissertation, Dept. of Field Crops, Coll. of Agric., Univ. of Baghdad, Pp: 116.

[9] Kabir, R., S. Yeasmin, A.K. Islam and M.A.R. Sarkan, 2013. Effect of phosphorus, calcium and boron on the growth and yield of groundnut (Arachis hypogaea L.) Inter. J. Biol. Sci. and Biol. Technol., 5(3): 51-59.

[10] Kamara, E.G., 2010. Effect of Calcium and Phosphorus Fertilization on the Growth, Yield and Seed Quality of Two Groundnuts (Arachis hypogaea L.) Varieties. M.Sc. Thesis, Coll. of Agric., Univ. of Sci., and Technol. Kumasi- GHANA, pp: 87.

[11] Onemli, F., 2005. The correlation analysis of some climate values with flowering and earliness index in peanut (Arachis hypogaea L.). J. Tek. Agric. Fac., 2: 273-281.

[12] Frimpong, A., 2004. Characterization of groundnut (Arachis hypogaea L.) in Northern Ghana. Pak. J., 7: 838-842.

[13] Yoldas, F. and D. Esiyok, 2005. The use of degree-day (C-days) on plant production. Egypt Univ., Agric. Fac. J., 42: 207-218.

[14] Canavar, O. and M.A. Kaynak, 2010. Growing degree day and sunshine radiation effects on peanut pod yield and growth. Afric. J. of Biotechnol., 9(15): 2234-2241.

[15] Ali, H.S. and S.F. Hassan, 2011. Peanut cultivation and production in Iraq. Directorate of Agric., Res., Ministry of Agric., pp: 23.

[16] Steel, R.G.D., J.H. Torrie and D.A. Dickey, 1997. Principles and procedures of statistics: a biometric approach, $3^{\text {rd }}$ Ed. McGraw Hill Book Co. Inc., New York. USA.

[17] Rajput, R.P., 1980. Response of soybean crop to climatic and soil environments. Ph.D. Thesis, IARI, Hew Delhi, India.

[18] Sardana, V. and S.S. Kandhola, 2007. Productivity of semi-spreading and bunch type verities of groundnut as influenced by sowing dates. J. SAT Agric. Res., 5(1): 1-4.

[19] Padmalatha,V., D.R. Reddy and T.Y. Reddy, 2006.The relationship between weather parameters during developmental phase and fruit attributes and yield of peanut. Peanut Sci., 33(2): 118-124.

[20] Veerabhadrappa, B.H. and N.A. Yeledhalli, 2005. Effect of soil and foliar application of nutrients on growth and yield of groundnut. Karnataka J. Agric. Sci., 18(3): 814-816.

[21] Patel,G.G., H.R. Patel, V. Pandey, A.M. Shekh, J.S. Patel, R.P. Vadodaria, B.K. Bhatt and J.C. Shroff, 2010. Influence of weather parameters on pod yield of groundnut in middle Gujarat agroclimatic region. J. Agrometeorol., 12(1): 77-80. 